\title{
ПРОСТРАНСТВЕННАЯ СТРУКТУРА ФОРМИРОВАНИЯ СТОКА НА ОСНОВЕ МАТЕМАТИЧЕСКОГО МОДЕЛИРОВАНИЯ
}

\author{
(C) 2020 г. Г. В. Пряхина ${ }^{a}$, Е. С. Зелепукина ${ }^{a, b}$, С. А. Гаврилкина ${ }^{a, *, * *}$, В. А. Соловьев ${ }^{a, c}$, \\ Н. И. Амбурцева ${ }^{d}$, Т. А. Виноградова ${ }^{a}$ \\ ${ }^{a}$ Санкт-Петербургский государственный университет, Институт наук о Земле, Санкт-Петербург, Россия \\ ${ }^{b}$ Санкт-Петербургский государственный университет телекоммуникаций им. проф. М.А.Бонч-Бруевича, \\ Санкт-Петербург, Россия \\ сООО “Эксперт ГАЗ”, Екатеринбург, Россия \\ ${ }^{d}$ Межспарламентская Ассамблея государств-участников Содружества Независимых Государств, \\ Санкт-Петербург, Россия \\ *e-mail: s.gavrilkina@spbu.ru \\ **e-mail: svetilnic@mail.ru \\ Поступила в редакцию 09.04.2019 г. \\ После доработки 08.09.2019 г. \\ Принята к публикации 28.11.2019 г.
}

\begin{abstract}
В работе приведены оценки стока с отдельных пространственных структурных частей водосборов, рассмотрена их роль в формировании интегрального стока с речных бассейнов северного макросклона Западного Саяна. В ходе ландшафтно-гидрологического анализа получена обобшенная база параметров почвенно-растительного покрова и поверхности склонов исследуемого региона. Возможность ее применения обоснована хорошими результатами сходимости моделируемых и наблюденных гидрографов суточных расходов воды. Количественно подтверждено, что на процессы формирования стока в различных типах лесов оказывают влияние состав доминирующих пород, сомкнутость древостоя, характер напочвенного покрова, выраженность уклонов. Преобладающие по площади водосборов таежные комплексы обеспечивают основной объем стока. Оценка вклада отдельных частей речных бассейнов в сток в замыкающем створе показала, что в пересчете на единицу площади наибольшие модули и коэффициенты стока характерны для гольцовых и тундровых комплексов. Для северного макросклона выявлено нарушение характера изменения модуля стока с высотой, связанное с особенностями снегонакопления в верхних частях водосборов.
\end{abstract}

Ключевые слова: моделирование стока, среднегорные водосборные бассейны, стокоформирующий комплекс, обобщенная база параметров почвенно-растительного покрова, Западный Саян

DOI: $10.31857 / \mathrm{S} 2587556620020107$

\section{ВВЕДЕНИЕ}

Выявление и последующая оценка влияния особенностей ландшафтов водосборных бассейнов на формирование стока является одной из важных теоретических задач гидрологии. Однако исследования, рассматривающие закономерности протекающих процессов в пределах горных водосборов, в целом не многочисленны вследствие труднодоступности горных территорий для исследований и разреженной гидрометеорологической сети постов и станций. В ряде работ $[1,20]$ оценивается гидрологическая роль ландшафтов, а также обобщенных структурных единиц водосборов - ландшафтно-гидрологических комплексов (далее - ЛГК). В качестве примера можно привести [5], в которой показаны результаты расчета стока с ЛГК, располагающихся на разных высотах, методом водного баланса. В [8, 11] при оценке стока с отдельных ЛГК авторы подчеркивают неизбежность существенных ошибок, возникающих при использовании мелкомасштабных ландшафтных карт, а также при осреднении величин стока и разложении расходов в замыкающем створе на сток с отдельных комплексов.

На сегодняшний день математическое моделирование представляется наиболее эффективным методом изучения процессов и факторов формирования стока, в том числе и стока с отдельных частей водосборов. Результаты моделирования стока с горных водосборов во многом зависят от качества входных данных и достоверности принимаемых значений параметров модели, которые в свою очередь определяются корректностью обобщения имеющейся информации о 


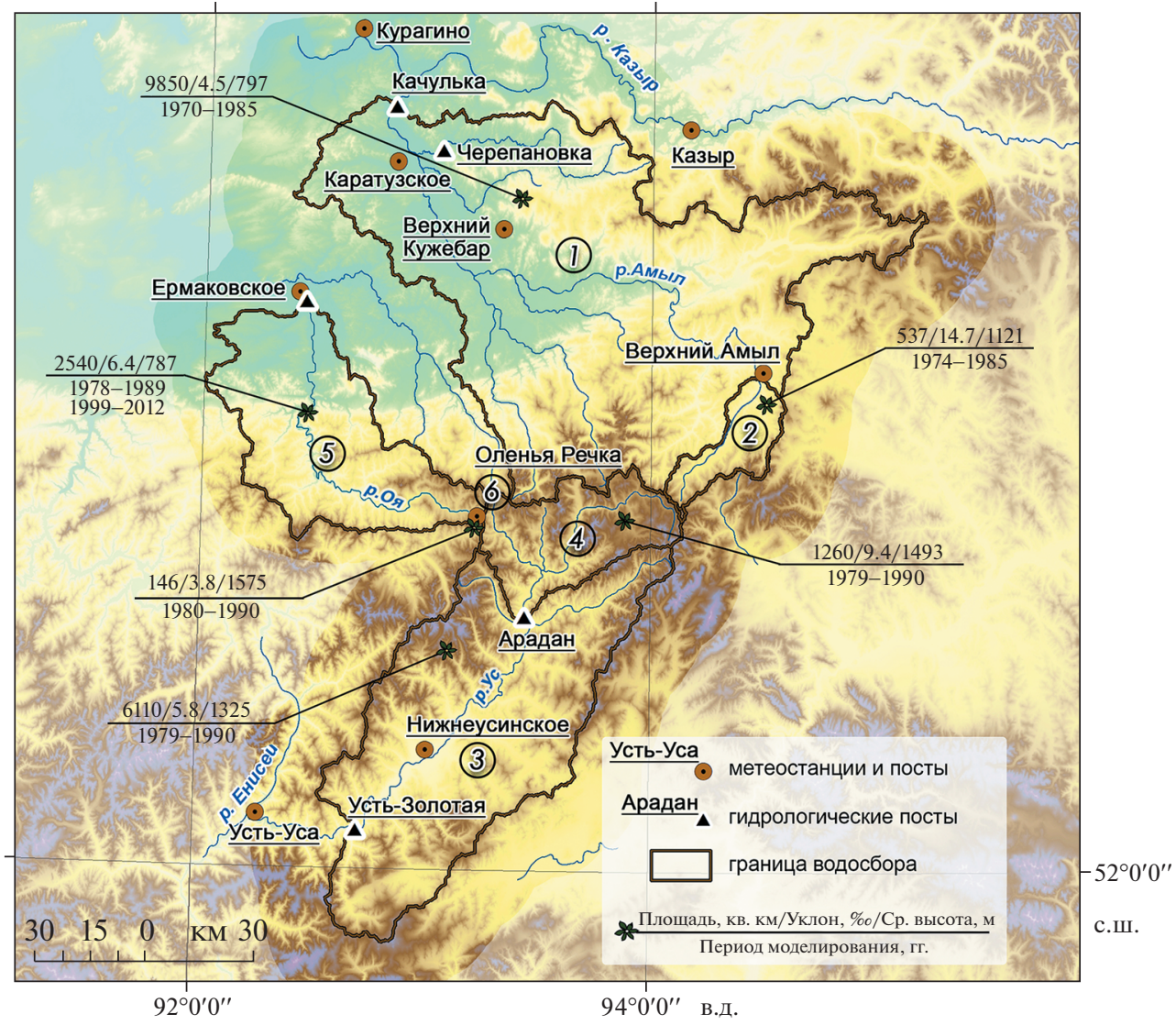

Рис. 1. Карта района исследования.

Цифрами обозначены водосборные бассейны: 1 - р. Амыл-с. Качулька, 2 - р. Амыл-пос. Верхний Амыл, 3 - р. Усд. Усть-Золотая, 4 - р. Ус-пос. Арадан, 5 - р. Оя-с. Ермаковское, 6 - р. Оленья речка-гм.п. Оленья речка.

факторах стокоформирования. Предложенная Ю.Б. Виноградовым [6] схематизация водосборов в виде стокоформирующих комплексов (далее СФК), с одной стороны, позволяет рассматривать бассейн реки как единую систему, преобразующую осадки, выпавшие на его поверхность, в интегральный сток в замыкающем створе, а с другой стороны, оценить роль и вклад отдельных частей водосбора в его формирование. Создание информационной базы обобщенных параметров СФК для определенного региона позволяет в условиях недостаточности данных о почвеннорастительном покрове горных водосборов применять методы моделирования для неизученных и малоизученных водосборов. В ходе многолетних экспедиционных работ на территории Алтае-Саянской горной страны авторами был собран значительный объем данных о характеристиках почвенно-растительного покрова, использованных в настоящей работе в качестве параметров модели. Целью представленной работы стало выявление роли отдельных частей речных бассейнов в фор- мировании стока с водосборов среднегорий юга Сибири на основе математического моделирования стока.

Гидрологический режим рек Западного Саяна характеризуется высоким весенне-летним половодьем, прерывистой низкой летне-осенней меженью с паводками, сопоставимыми по высоте с половодьем, и устойчивой низкой зимней меженью [17]. Выбор в качестве модельных водосборов бассейнов рр. Амыл (левый приток р. Туба), Оя и Ус (правые притоки Енисея) был обусловлен наличием на этих водотоках не менее двух действующих гидрологических постов, что позволило рассмотреть отдельные части водосборов с точки зрения их вклада в формирование стока (рис. 1). По [17] коэффициенты заболоченности и озерности водосборов не превышают $2 \%$, а залесенность территорий достигает 90\%. Период моделирования для каждого водосбора определялся наличием данных наблюдений на метеорологических станциях и гидрологических постах. 


\section{МАТЕРИАЛЫ И МЕТОДЫ}

В исследовании использовалась детерминированная гидрологическая модель процессов формирования стока "Гидрограф" с распределенными параметрами [7], которая показала свое успешное применение для бассейнов разной величины и расположения [23]. В качестве входной информации в модели используются стандартные метеорологические данные (температура, дефицит влажности воздуха или относительная влажность воздуха, продолжительность и слой осадков и др.), как правило, с суточным разрешением. Помимо гидрографов, модель позволяет рассчитывать элементы водного баланса бассейна и его переменные состояния [18].

Основной принцип выделения СФК в горных условиях основан на дифференциации территории по величине уклона, составу подстилающих пород, степени дренированности, наличию почвенно-растительного покрова, типу растительных сообществ и характеристикам ярусов, наличию других водных объектов. Выделение стокоформирующих комплексов Западного Саяна проводилось на основе ландшафтной карты (масштаб $1: 500000)$, составленной авторами.

Параметры модели характеризуют СФК в целом, неизменны в его пределах, скачкообразно изменяются на его границах и представлены тремя группами: параметры растительного покрова, почвенного профиля и поверхности склона. Обобщение порядка 300 полевых ландшафтных описаний позволило для каждого СФК уточнить диапазоны значений таких параметров модели, как:

- максимальная/минимальная сезонная затененность кронами деревьев (назначалась с учетом видового состава и проективного покрытия);

- максимальная/минимальная емкость перехвата осадков всеми ярусами растительности (по [16] с учетом проективного покрытия каждого яруса);

- максимальное/минимальное альбедо (назначалось по [2, 9] с учетом ландшафтных описаний);

- максимальный/минимальный коэффициент испаряемости (рассчитывался по [12] для теплого и холодного периодов соответственно по данным ближайших к расчетной точке модели метеостанций [19] - дефицит влажности, месячная сумма прямой солнечной радиации - с учетом полученных значений затененности кронами и альбедо поверхности).

Для описания водно- и теплофизических процессов в почве в модели для каждого расчетного слоя почвы (далее - РСП) глубиной 0.1 м были заданы параметры по справочным данным [13, 14] в соответствии с характеристиками почвы, полученными по полевым описаниям почвенных разрезов; количество РСП, выделенных для кон- кретного СФК зависело от глубины почвенного профиля. Исключением стали значения коэффициентов фильтрации, рассчитанные по данным непосредственных измерений с помощью кольцевого инфильтрометра EIJKELKAMP P 09.04. Подчеркнем, что значения параметров в ходе моделирования не корректировались.

Результаты моделирования оценивались путем сравнения критериев эффективности НэшаСатклиффа (NS) [21], рекомендованного Американской ассоциацией гражданских инженеров, а также Всемирной метеорологической организацией для оценки состоятельности моделей стока [22]. Обычно моделирование признается удовлетворительным при NS $>0.5$.

\section{РЕЗУЛЬТАТЫ И ОБСУЖДЕНИЕ}

В связи с малой эффективностью использования мелкомасштабных карт из-за высокой степени генерализации информации (особенно при выделении СФК малых водосборов) для исследуемого региона была разработана обобщенная схема выделения СФК (рис. 2) на основе среднемасштабной ландшафтной карты. Следует добавить, что на предлагаемой схеме представлены два типа СФК (отмечены *), которые в модельных расчетах не использовались, так как расположены за пределами ключевого участка, однако они отражают типичные условия стокоформирования семиаридных ландшафтов предгорий южного макросклона Западного Саяна (Туранская и Тувинская котловины).

Информационная база параметров гидрологической модели представляет собой набор таблиц обобщенных значений для каждого СФК. В частности, для параметров растительного покрова представлены интервалы значений затененности, емкости перехвата, альбедо и др. (табл. 1).

При изучении водного режима средних и, особенно, малых горных рек недостаточная обеспеченность данными гидро- и метеонаблюдений может быть частично компенсирована за счет детального учета ландшафтной дифференциации территории. Мозаичность современного растительного покрова северного макросклона Западного Саяна обусловлена масштабными сплошными рубками второй половины XX в. В настоящее время от 30 до $60 \%$ площади водосборов занимают мелколиственно-хвойные леса (СФК 6), представляющие собой различные промежуточные стадии восстановительных сукцессий. В отличие от коренных темнохвойных лесов (СФК 9) значительное участие в производных древостоях лиственных пород (березы и осины) определяет более высокую пропускающую способность крон, меньшую емкость перехвата, более значительную сезонную изменчивость величины альбедо и т.п. 


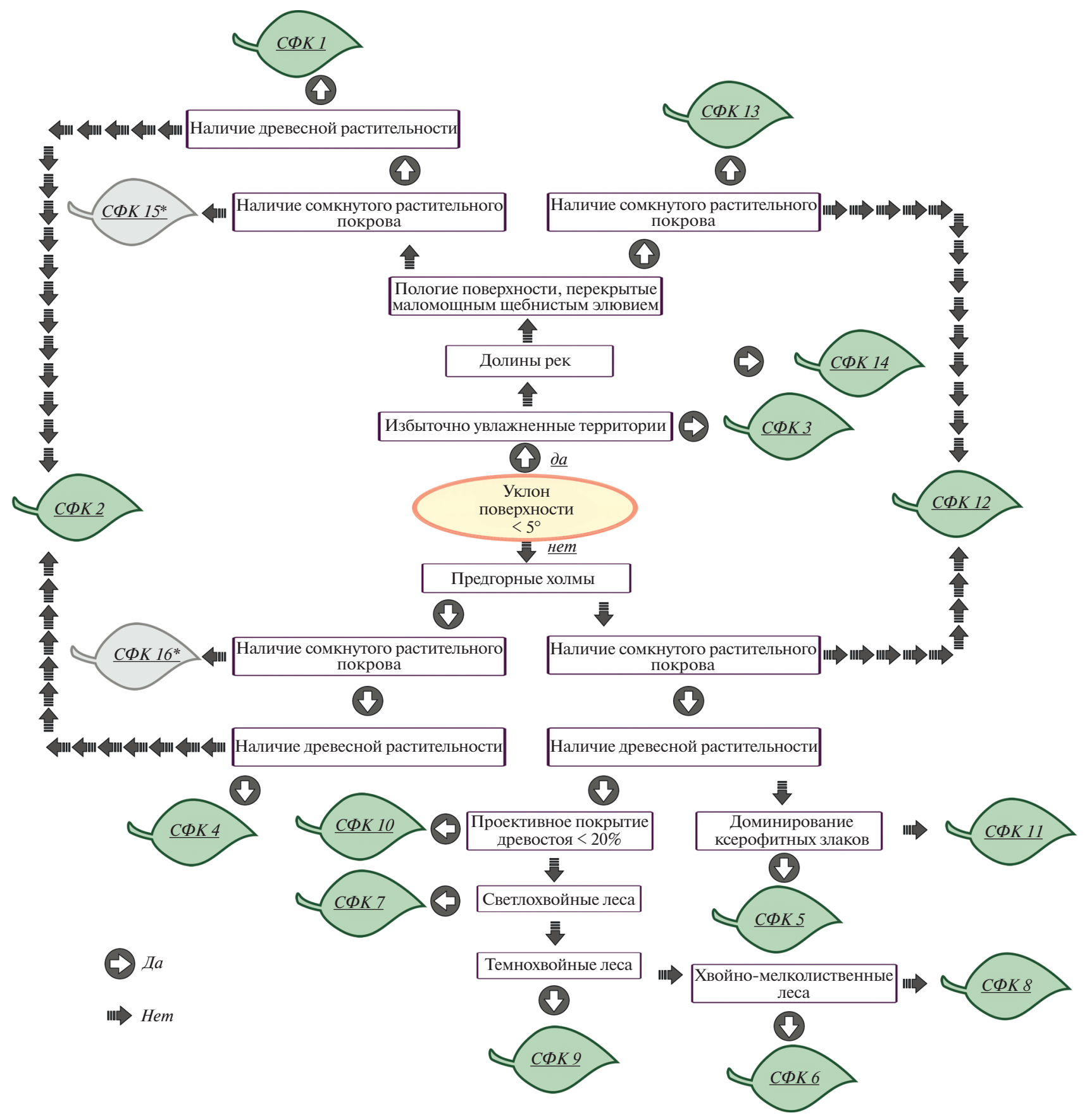

Рис. 2. Блок-схема выделения СФК: 1 - мелколиственные леса на равнинах; 2 - сельскохозяйственные угодья на равнинах и холмистых предгорьях; 3 - низинные или переходные болота, местами облес енные; 4 - мелколиственнохвойные леса на холмистых предгорьях; 5 - степи на среднекрутых склонах; 6 - мелколиственно-хвойные леса на среднекрутых склонах; 7- лиственничные с березой леса на среднекрутых склонах; 8 - темнохвойные с лиственницей леса на среднекрутых склонах; 9 - темнохвойные леса на среднекрутых склонах; 10 - редкостойные темнохвойные леса на среднекрутых склонах; 11 - тундры и луга на среднекрутых склонах; 12 - гольцовые комплексы вершин и среднекрутых склонов; 13 - хвойные леса на выположенных вершинах; 14 - долинные мелколиственные и хвойные леса; $15^{*}$ - опустыненные степи на равнинах; $16^{*}$ - полупустыни на мелкосопочниках.

Таким образом, даже при незначительном изменении лесистости при гидрологическом моделировании значение имеет учет изменений соотношения разных типов лесов.
Значительно меняются в верхних горизонтах почвы почвенные параметры: плотность, пористость, коэффициент фильтрации и др. (табл. 2). Для большинства СФК они задавались неизмен- 
Таблица 1. Параметры растительного покрова СФК (фрагмент)

\begin{tabular}{|c|c|c|c|c|c|c|c|c|}
\hline \multirow[t]{2}{*}{ СФК } & \multicolumn{2}{|c|}{$\begin{array}{c}\text { Затененность } \\
\text { кронами деревьев, б/p }\end{array}$} & \multicolumn{2}{|c|}{$\begin{array}{c}\text { Емкость перехвата ярусами } \\
\text { растительности*, мм }\end{array}$} & \multicolumn{2}{|c|}{$\begin{array}{c}\text { Альбедо за } \\
\text { вегетационный период, } \\
\text { б/p }\end{array}$} & \multicolumn{2}{|c|}{$\begin{array}{c}\text { Коэффициент } \\
\text { испаряемости, } \\
10 \mathrm{e}^{-8} /(\text { ГПа с) }\end{array}$} \\
\hline & $\min$ & $\max$ & $\min$ & $\max$ & $\min$ & $\max$ & $\min$ & $\max$ \\
\hline 1 & 0.20 & 0.50 & 1.0 & 4.0 & 0.15 & 0.20 & 0.10 & 0.26 \\
\hline 2 & 0.00 & 0.05 & 0.5 & 1.2 & 0.10 & 0.25 & 0.09 & 0.24 \\
\hline 4 & 0.10 & 0.50 & 1.0 & 4.6 & 0.15 & 0.20 & 0.09 & 0.26 \\
\hline 6 & 0.10 & 0.40 & 1.0 & 4.6 & 0.15 & 0.20 & 0.09 & 0.26 \\
\hline 7 & 0.15 & 0.30 & 1.0 & 4.6 & 0.10 & 0.25 & 0.10 & 0.25 \\
\hline 8 & 0.10 & 0.40 & 1.0 & 4.6 & 0.10 & 0.20 & 0.09 & 0.25 \\
\hline 9 & 0.35 & 0.60 & 1.5 & 5.0 & 0.10 & 0.15 & 0.10 & 0.27 \\
\hline 10 & 0.10 & 0.30 & 1.0 & 3.0 & 0.10 & 0.20 & 0.09 & 0.25 \\
\hline 11 & 0.00 & 0.00 & 1.0 & 2.5 & 0.15 & 0.25 & 0.09 & 0.24 \\
\hline 12 & 0.00 & 0.00 & 0.0 & 0.5 & 0.10 & 0.15 & 0.09 & 0.23 \\
\hline 14 & 0.15 & 0.55 & 1.0 & 4.5 & 0.10 & 0.20 & 0.10 & 0.26 \\
\hline
\end{tabular}

* При отсутствии специальных данных минимальные значения емкости перехвата принимались 20-35\% от максимальных (с точностью до 0.5$)$.

Таблица 2. Параметры почвенного профиля СФК (фрагмент)

\begin{tabular}{|c|c|c|c|c|c|c|c|c|c|c|c|c|}
\hline \multirow{2}{*}{$\begin{array}{c}\text { Глубина, } \\
\text { см }\end{array}$} & \multicolumn{4}{|c|}{ СФК 1} & \multicolumn{4}{|c|}{ СФК 9} & \multicolumn{4}{|c|}{ СФК12 } \\
\hline & 1 & 2 & 3 & 4 & 1 & 2 & 3 & 4 & 1 & 2 & 3 & 4 \\
\hline 10 & \multirow{2}{*}{$\begin{array}{l}\text { Гумусо- } \\
\text { вый }\end{array}$} & 1300 & 0.80 & 2.50 & Гумусовый & 1300 & 0.80 & 2.50 & Грубогумусовый & 1300 & 0.80 & 2.50 \\
\hline 20 & & 2400 & 0.55 & 2.00 & \multirow{3}{*}{$\begin{array}{l}\text { Супесь, } \\
30-60 \%\end{array}$} & 2600 & 0.50 & 0.89 & \multirow{2}{*}{$\begin{array}{l}\text { Супесь, } \\
>60 \%\end{array}$} & 2700 & 0.50 & 0.88 \\
\hline 30 & \multirow{2}{*}{$\begin{array}{l}\text { л/сугли- } \\
\text { нок, 0\% }\end{array}$} & 2550 & 0.50 & 1.50 & & 2700 & 0.45 & 0.50 & & 2700 & 0.45 & 0.35 \\
\hline 40 & & 2700 & 0.45 & 1.00 & & 2700 & 0.45 & 0.50 & \multirow{4}{*}{$\begin{array}{l}\text { Коренная } \\
\text { порода }\end{array}$} & 2750 & 0.35 & 0.35 \\
\hline 50 & \multirow{3}{*}{$\begin{array}{l}\text { л/сугли- } \\
\text { нок, } \\
0 \%\end{array}$} & 2700 & 0.40 & 0.20 & \multirow{3}{*}{$\begin{array}{l}\text { Коренная } \\
\text { порода }\end{array}$} & 2700 & 0.35 & 0.05 & & 2750 & 0.35 & 0.35 \\
\hline 60 & & 2700 & 0.35 & 0.10 & & 2750 & 0.35 & 0.05 & & 2750 & 0.35 & 0.35 \\
\hline 70 & & 2750 & 0.35 & 0.05 & & 2750 & 0.35 & 0.05 & & 2750 & 0.35 & 0.35 \\
\hline
\end{tabular}

Примечания. 1 - механический состав, щебнистость, \%; 2 - плотность расчетных слоев почвы, кг/м³; 3 - пористость расчетных слоев почвы, б/p; 4 - коэффициент фильтрации, мм/мин.

ными ниже 60-70 см от поверхности; для СФК 12 (гольцовые комплексы вершин и среднекрутых склонов) - ниже 30 см, и только для СФК 2 (сельскохозяйственные земли) задавались 10 расчетных слоев почвы. В целом на исследуемой территории преобладают супесчаные почвы различной щебнистости (от 0 до 80\%). Более тяжелые по гранулометрическому составу почвы характерны для северных предгорий Западного Саяна и Минусинской котловины (СФК 1 и СФК 2).

Наличие значительного числа полевых описаний почвенных разрезов и измерений фильтрационной способности почв позволило для каждого СФК более корректно назначить значения водно-физических параметров по глубине профиля и существенно сузить диапазон изменения коэффициента фильтрации для каждого РСП (расчетного слоя), что заметно повысило сходимость результатов моделирования [15] и, несомненно, приблизило смоделированные условия формирования стока к реальным.

Результаты модельных расчетов с использованием обобщенных значений параметров продемонстрировали хорошую сходимость с наблюденными значениями расходов воды. Среднее значение критерия эффективности Нэша-Сатклиффа для исследуемых бассейнов составило 0.74 , максимальное -0.91 (рис. 3). Отклонения рассчитанных и наблюденных средних годовых расходов воды не превышают $6 \%$, среднее отклонение составляет $1.6 \%$ [24]. 


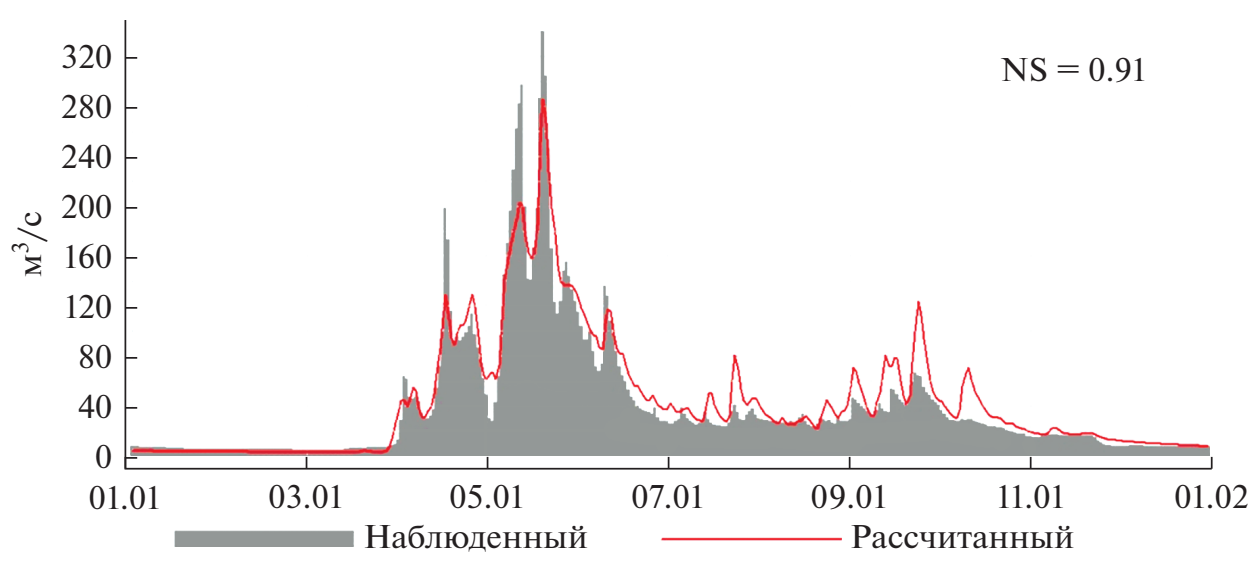

Рис. 3. Рассчитанный и наблюденный гидрографы стока р. Оя-с. Ермаковское с высокой сходимостью результатов (2001 г.).

Результаты моделирования (при отсутствии корректирующих коэффициентов) свидетельствуют об адекватности обобщенных для региона значений параметров, а значит позволяют с высокой степенью достоверности оценить сток с отдельных стокоформирующих комплексов водосбора за расчетный период и выполнить оценку их вклада в формирование стока в замыкающем створе.

Выполненный анализ показал, что наибольшие объемы стока в исследуемом регионе характерны для преобладающих по площади лесопокрытых территорий, при этом гидрологическая роль разных типов леса отличается.

Особенность формирования стока в темнохвойных лесах на склонах (СФК 9) обеспечивается наложением нескольких факторов: относительно высокая влажность и низкое испарение под пологом леса в сочетании с высокой влагоемкостью напочвенного покрова, представленного хорошо развитым моховым ярусом (проективное покрытие $>70 \%$ ), а также значительная водопроницаемость верхних горизонтов. Как следствие, в подавляющем большинстве случаев выпадения осадков поверхностный сток не формируется, основная часть влаги переходит в почвенный сток. В ходе полевых исследований авторы неоднократно наблюдали процесс заполнения почвенного разреза водой, просачивающейся из горизонтов на глубине 30-40 см от поверхности. Задержание атмосферной влаги в подстилке, перевод ее в почвенный сток увеличивают время добегания, а, следовательно, период водоотдачи с территории СФК, обеспечивая, таким образом, водорегулируюшую роль темнохвойных лесов.

Микроклиматические особенности лиственничных лесов (СФК 7), распространенных на склонах в семиаридных условиях (южнее хр. Араданский), заключаются в более выраженной сезонной изменчивости величины затененности и альбедо (в результате сброса хвои), что приводит к увеличению доли осадков, достигающих поверхности. В то же время низкая влагоемкость напочвенного покрова, представленного ксерофитными злаками и хвойным опадом, и высокая проницаемость легких по гранулометрическому составу слагающих пород обусловливают отсутствие поверхностного стока. Таким образом, бо́льшая часть поступающих атмосферных осадков идет на формирование стока более глубоких водоносных горизонтов. Об этом косвенно свидетельствуют рассчитанные по модели значения коэффициентов стока светлохвойных лесов $(0.37-0.42)$, которые ниже, чем темнохвойных (табл. 3), что соотносится с данными [8].

Резкое уменьшение площади темнохвойных лесов в результате массовых рубок в середине $\mathrm{XX}$ в. привело к заметному изменению гидрологического режима рек низкогорий и среднегорий. В настоящее время в ходе последовательных динамических сукцессий происходит постепенное восстановление структуры, а вместе с ней и стокоформирующих функций исходного темнохвойного леса, причем темпы восстановления водорегулирующих свойств древостоя соответствуют в исследуемом регионе экспериментальным оценкам [4].

Наименьшие модули стока характерны для равнинных территорий. В связи с незначительными уклонами, потенциально более высокой теплообеспеченностью низких гипсометрических уровней, и наличием обширных территорий с длительным застойным увлажнением значения модулей стока мелколиственных с участием хвой-

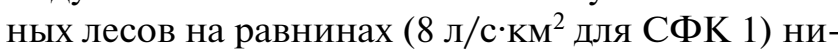
же модулей стока со склонов, покрытых лесами.

В целом наибольшие коэффициенты и модули годового стока характерны для верхних частей водосборов с широким распространением выходов скальных пород, маломощным покровом поверх- 
Таблица 3. Рассчитанные характеристики стока с различных СФК

р. Амыл-с. Качулька

\begin{tabular}{|c|c|c|c|c|c|c|c|c|c|c|c|}
\hline \multirow{2}{*}{$\begin{array}{c}\text { Рассчитанные } \\
\text { характеристики }\end{array}$} & \multicolumn{11}{|c|}{ СФК } \\
\hline & 1 & 2 & 4 & 6 & 7 & 8 & 9 & 10 & 11 & 12 & 14 \\
\hline Слой стока, мм & 238 & 399 & 509 & 699 & - & - & 767 & 936 & 1117 & - & 327 \\
\hline Коэффициент стока, б/p & 0.34 & 0.50 & 0.51 & 0.62 & - & - & 0.65 & 0.70 & 0.75 & - & 0.43 \\
\hline$\frac{\text { Доля стока }}{\text { Доля площади }}$, б/p & 0.40 & 0.60 & 0.76 & 1.10 & - & - & 1.19 & 1.36 & 1.63 & - & 0.40 \\
\hline Модуль стока, л/с км² & 8 & 13 & 16 & 22 & - & - & 24 & 30 & 35 & - & 10 \\
\hline
\end{tabular}

Слой стока, мм

Коэффициент стока, б/p $\frac{\text { Доля стока }}{\text { Доля площади }}$, б/p

Модуль стока, л/с км²

Слой стока, мм

Коэффициент стока, б/p $\frac{\text { Доля стока }}{\text { Доля площади }}$, б/p

Модуль стока, л/с км²

Слой стока, мм

Коэффициент стока, б/p Доля стока

Доля площади, б/p

Модуль стока, л/с·км²

Слой стока, мм

Коэффициент стока, б/р

$\frac{\text { Доля стока }}{\text { Доля плошади }}$, б/p

Модуль стока, л/с·км²

Слой стока, мм

Коэффициент стока, б/p

$\frac{\text { Доля стока }}{\text { Доля площади }}$, б/p

Модуль стока, л/с·км² p. Амыл-пос. Верхний Амыл

\begin{tabular}{l|c|c|c|c|c|c|c|c|c} 
р. Амыл-пос. Верххий Амыл \\
- & - & 473 & - & - & 543 & 593 & 670 & - & - \\
- & - & 0.56 & - & - & 0.59 & 0.61 & 0.68 & - & - \\
- & - & 0.88 & - & - & 1.00 & 1.10 & 1.17 & - & - \\
- & - & 15 & - & - & 17 & 19 & 21 & - & -
\end{tabular}

р. Ус-д. Усть-Золотая

\begin{tabular}{c|c|c|c|c|c|c|c|c}
260 & 218 & 304 & 317 & 356 & 505 & 486 & - \\
0.41 & 0.37 & 0.43 & 0.47 & 0.51 & 0.59 & 0.57 & - \\
- & & & & & & & \\
- & 0.76 & 0.64 & 0.89 & 0.91 & 1.10 & 1.47 & 1.30 & - \\
- & 7 & 10 & 10 & 11 & 16 & 15 & -
\end{tabular}

p. Ус-пос. Арадан

\begin{tabular}{l|c|c|c|c|c|c|c|c}
- & 734 & - & 583 & 705 & 1013 & 980 & 1233 & - \\
- & 0.67 & - & 0.62 & 0.67 & 0.76 & 0.76 & 0.78 & - \\
- & 0.88 & - & 0.75 & 0.84 & 1.11 & 1.16 & 1.5 & - \\
- & 23 & - & 18 & 20 & 32 & 31 & 39 & -
\end{tabular}

р. Оя-с. Ермаковское

\begin{tabular}{c|c|c|c|c|c|c|c|c}
304 & 251 & - & 559 & - & 1044 & - & - \\
0.47 & 0.42 & - & 0.61 & - & 0.81 & - & - \\
- & & & & & & & \\
- & 0.50 & - & 1.19 & - & 2.25 & - & - \\
& & 8 & - & 18 & - & 33 & - & -
\end{tabular}

р. Оленья речка-гм.п. Оленья речка

\begin{tabular}{l|c|c|c|c|c|c|c|c|c}
- & - & - & - & - & 1008 & - & 1091 & - & - \\
- & - & - & - & - & 0.76 & - & 0.81 & - & - \\
- & - & - & - & - & 0.82 & - & 1.14 & - & - \\
& & & & & & & & & - \\
- & - & - & - & - & 32 & - & 35 & - & -
\end{tabular}


ностных отложений с низкими фильтрационными свойствами, что приводит к быстрому стоку талых и дождевых вод в русла дренирующих водотоков. Коэффициент стока тундрово-луговых среднегорий и гольцовых комплексов вершин и среднекрутых склонов (СФК 11 и 12 соответственно) достигает 0.81 .

Отметим, что в связи со значительной сезонной изменчивостью ряда параметров отдельных СФК, их роль в формировании интегрального стока в разные фазы водного режима может меняться; однако этот вопрос в рамках данного исследования не рассматривался.

Сопоставление объемов стока с отдельных СФК выявило приоритетное значение в формировании годового стока безлесных участков, занимающих второстепенное положение по площади. Так, отношение доли стока к доле площади для СФК 12 составляет 1.5, а для СФК 11 достигает 2.23 .

Анализ объемов стока, формирующихся на различных высотных интервалах показал, что в бассейнах pp. Ус и Оя наибольший вклад в формирование стока вносят верхние части бассейна, в то время как в бассейне р. Амыл модуль стока с высотой уменьшается: значения модулей стока в нижнем течении (с. Качулька) составляет 21.7 л/с км², в среднем течении (пос. Верхний Кужебар) 27.7 л/с км², а в верхнем течении (пос. Верхний Амыл) - 18.8 л/с км². Вероятно, это объясняется не только уменьшением твердых атмосферных осадков, перевеваемых преобладающими северозападными ветрами на подветренные склоны [10], но и с уменьшением запасов воды в снежном покрове региона [3].

\section{ЗАКЛЮЧЕНИЕ}

Высокая сходимость рассчитанных и наблюденных гидрографов суточных расходов воды позволила оценить среднемноголетние величины стока с различных стокоформирующих комплексов и рассчитать их вклад в формирование стока горных рек. Для территории Западного Саяна расчет стока с отдельных СФК методом математического моделирования выполнен впервые.

Доминирующие в исследуемом регионе таежные комплексы обеспечивают основной объем стока. Темнохвойные и светлохвойные леса в основном переводят выпадающие осадки в почвенный и подземный сток, не формируя поверхностного стока. Результаты модельных расчетов продемонстрировали отличия таких гидрологических характеристик, как модуль и коэффициент стока для лесов, отличающихся по составу доминирующих пород, сомкнутости древостоя, характеру напочвенного покрова, выраженностью и крутизной уклонов.
Оценка вклада отдельных частей речных бассейнов в сток в замыкающем створе показала, что в пересчете на единицу площади наибольшие модули и коэффициенты стока характерны для гольцовых и тундровых комплексов.

Наиболее значимую долю в общий сток (до $60 \%$ ) вносят верхние части водосборов (как правило, выше 900 м), выполняя, таким образом, основную стокоформирующую роль. Анализ распределения модулей стока показал, что не всегда происходит его увеличение с высотой. Так, при формировании стока р. Амыл наблюдается уменьшение модуля стока к верхней части бассейна из-за особенностей снегонакопления.

Адекватность обобщенной базы параметров почвенно-растительного покрова для СФК водосборов горной части Западного Саяна (за счет уточнения диапазонов значений по данным полевых наблюдений) подтверждена хорошими результатами моделирования и, соответственно, может быть применена для моделирования стока с неизученных бассейнов, располагающихся в схожих условиях.

\section{СПИСОК ЛИТЕРАТУРЫ}

1. Антипов А.Н., Гагаринова О.В., Федоров В.Н. Ландшафтная гидрология: теория, методы, реализация // Геогр. и природные ресурсы. 2007. № 3. С. 56-66.

2. Будыко М.И. Тепловой баланс земной поверхности. Л., 1956. $256 \mathrm{c.}$

3. Бураков Д.А., Гордеев И.Н. Оценка предвесенних снегозапасов в бассейнах Красноярского и СаяноШушенского водохранилищ // Геогр. и природные ресурсы. 2013. № 1. С. 72-78.

4. Буренина Т.А., Овчинникова Н.Ф., Федотова Е.В. Изменение структуры водного баланса на вырубках черневой тайги Западного Саяна // Геогр. и природные ресурсы. 2011. № 1. С. 92-100.

5. Буренина Т.А., Федотова Е.В., Овчинникова Н.Ф. Изменение структуры влагооборота в связи с возрастной и восстановительной динамикой лесных экосистем // Сиб. экол. журн. 2012. Т. 5. № 3. C. $323-331$.

6. Виноградов Ю.Б. Математическое моделирование процессов формирования стока. Критический анализ. Л.: Гидрометеоиздат, 1988. $312 \mathrm{c.}$

7. Виноградов Ю.Б., Виноградова Т.А. Математическое моделирование в гидрологии. М.: Издательский центр “Академия”, 2010. 298 с.

8. Гагаринова О.В. Ландшафтно-гидрологические закономерности формирования стока в бассейне озера Байкал // Геогр. и природные ресурсы. 2012. № 3. С. $55-60$.

9. Гаевский В.Л. Альбедо больших территорий // Тр. ГГО. 1961. Вып. 109. С. 61-75.

10. Геткер М.И., Жданов А.А. Закономерности распределения высоты и плотности снежного покрова в горно-таежных районах Саян // Тр. САНИГМИ. 1992. Вып. 146 (227). С. 56-63. 
11. Горошко Н.В. Ландшафтно-гидрологический анализ годового стока в бассейне Верхней Оби. Автореф. дис. ... канд. геогр. наук. Иркутск, 2007. 270 с.

12. Зубенок Л.И. Испарение на континентах. Л.: Гидрометеоиздат, 1976. 295 с.

13. Качинский Н.А. Физика почв. М., 1965. 318 с.

14. Корчагин А.А., Мазиров М.А., Шушкевич Н.И. Физика почв: лаб. Практикум. Владимир: Изд-во Владим. ун-та, 2011. 99 с.

15. Пряхина Г.В., Зелепукина Е.С., Журавлев С.А., Осипова Т.Н., Амбурцева Н.И., Виноградова Т.А. Оценка стока с малых горных водосборов методами гидрологического моделирования // Вестн. Моск. унта. Сер. 5. География. 2017. № 1. С. 29-37.

16. Рахманов В.В. Гидроклиматическая роль лесов. М.: Лесн. пром-сть, 1984. 240 с.

17. Ресурсы поверхностных вод СССР. Основные гидрологические характеристики / отв. ред. Е.Э. Булаховской. Л.: Гидрометеоиздат, 1977. Т. 16. Вып. 1. $388 \mathrm{c}$.

18. Свидетельство о государственной регистрации программы для ЭВМ №2018619084 «Комплексная программа распределенной гидрологической модели “Гидрограф”», правообладатель О.М. Макарьева. Дата регистрации 30.07.2018.

19. Научно-прикладной справочник по климату СССР. Гидрометслужба СССР. Л.: Гидрометеоиздат, 1967. Вып. 21. Кн. 1. Красноярский край и Тувинская АССР. 504 с.
20. Цимбалей Ю.М., Андреева И.В. Учет ландшафтной структуры водосборов при оценке водного баланса водоприемников (на примере бессточной области Обь-Иртышского междуречья) // Изв. Алтайского отд. Русского географического общества. 2015. № 1 (36). C. 23-30.

21. Nash J.E., Sutcliffe J.V. River flow forecasting through conceptual models // A discussion of principles. 1970. V. 10. № 3. P. 282-290.

22. Semenova O.M. Experience in modelling runoff formation processes at different scales using data of water-balance stations // Status and Perspectives of Hydrol. in Small Basins IAHS Publ. № 336. 2010. P. 167-172.

23. Shamseldin A.Y., O'Connor K.M. A Non-Linear Neural Network Techniquefor Updating of River Flow Forecasts // Hydrol. and Earth Sys. Sci. 2001. V. 5. № 4. P. 577-598.

24. Vinogradov Y.B., Semenova (Makarieva) O.M., Vinogradova T.A. An approach to the scaling problem in hydrological modelling: the deterministic modelling hydrological system // Hydrol. Processes. V. 25. № 7. P. 1055-1073.

25. Zelepukina E., Pryakhina G., Shastina G., Amburtceva N., Gavrilkina $S$. Estimation of small mountain drainage basin runoff based on runoff formation model (West Sayan case study) / 17th Intern. multidisciplinary scientific geoconference SGEM 2017. Conf. proceedings 17 - Water resources, forest, marine and ocean ecosystems 31 - Hydrology and water resources, marine and ocean ecosystems. 2017. V. 17. № 31. P. 245-252.

\title{
Mathematical Modeling of Runoff Formation Spatial Structure
}

\author{
G. V. Pryakhina1 ${ }^{\text {, E. S. Zelepukina }}{ }^{1,2}$, S. A. Gavrilkina ${ }^{1, \#, \# \#, ~ V . ~ A . ~ S o l o v y e v ~}{ }^{1,3}$, \\ N. I. Amburtseva ${ }^{4}$, and T. A. Vinogradova ${ }^{1}$ \\ ${ }^{1}$ Saint Petersburg State University, Institute of Earth Sciences, Saint Petersburg, Russia \\ ${ }^{2}$ The Bonch-Bruevich Saint-Petersburg State University of Telecommunications, Saint Petersburg, Russia \\ ${ }^{3}$ LLC Expert GAZ, Yekaterinburg, Russia \\ ${ }^{4}$ Interparliamentary Assembly of Member Nations of the Commonwealth of Independent States (IPA CIS), \\ Saint Petersburg, Russia \\ \#e-mail: s.gavrilkina@spbu.ru \\ \#\#-mail: svetilnic@mail.ru
}

Runoff estimation of drainage basin's different spatial structural parts is presented in the research. The hydrological role of runoff-forming complexes is considered by the case study of the northern macroslope of the Western Sayan Mountains. The aggregate database of vegetation, soil and slope characteristics (hydrological parameters for modelling) was received during of investigated region's analysis. The base's applicability is justified by high results of calculated and obtained daily water discharge hydrographs' convergence. An effect of different forest types characteristics (species composition, tree crown cover, slope steepness, soil, vegetation and other) in the runoff forming was quantitative confirmed. Water discharge is mainly provided by taiga geosystems which are prevail in water catchment areas investigated. According to the assessment of drainage basin different parts' contribution to runoff the largest runoff modules and rates per unit of area are observed in nival geosystems and mountain tundras. Inconsistency of the runoff modules changing with altitude related to features of snow storage in the upper mountain levels of the Sayan Mountains' northern macroslope was revealed.

Keywords: hydrological modelling, runoff forming complexes, aggregate database, vegetation and soil cover characteristics, Western Sayan Mountains 


\section{REFERENCES}

1. Antipov A.N., Gagarinova O.V., Fedorov V.N. Landscape hydrology: theory, methods and implementation. Geogr. Prir. Resur., 2007, no. 3, pp. 56-66. (In Russ.).

2. Budyko M.I. Teplovoi balans zemnoi poverhnosti [The Heat Balance of the Surface of the Earth]. Leningrad: Gidrometeoizdat Publ., 1956. 256 p.

3. Burakov D.A., Gordeev I.N. Assessing snow storage within the catchments of the Krasnoyarsk and SayanoShushenskoe reservoirs. Geogr. Prir. Resur., 2013, no. 1, pp. 72-78. (In Russ.).

4. Burenina T.A., Ovchinnikova N.F., Fedotova E.V. Changes in the water balance structure in cutover areas of the dark-coniferous taiga in the Western Sayan. Geogr. Prir. Resur., 2011, no. 1, pp. 92-100. (In Russ.).

5. Burenina T.A., Fedotova E.V., Ovchinnikova N.F. Change in the structure of the hydrological cycle in connection with the age and recovery dynamics of forest ecosystems. Contemp. Probl. Ecol., 2012, vol. 5, no. 3 , pp. $323-331$.

6. Vinogradov Yu.B. Matematicheskoe modelirovanie protsessov formirovaniya stoka. Kriticheskii analiz [Hydrograph Simulation of Runoff Formation Processes. Critical Analysis]. Leningrad: Gidrometeoizdat Publ., 1988. $312 \mathrm{p}$.

7. Vinogradov Yu.B., Vinogradova T.A. Matematicheskoe modelirovanie $v$ gidrologii [Mathematical Modeling in Hydrology]. Moscow: Akademiya Publ., 2010. 298 p.

8. Gagarinova O.V. Landscape-hydrological regularities of runoff formation within the Lake Baikal watershed basin. Geogr. Prir. Resur., 2012, no. 3, pp. 55-60. (In Russ.).

9. Gaevskii V.L. Albedo of large areas. Tr. GGO, 1961, no. 109, pp. 61-75. (In Russ.).

10. Getker M.I., Zhdanov A.A. The pattern of distribution of snow cover height and density in Sayan mountain-taiga areas. Tr. SANIGMI. 1992, vol. 146 (227), pp. 56-63. (In Russ.).

11. Goroshko N.V. Landscape-hydrological analyses of annual discharge in the Upper $\mathrm{Ob}$ basin. Cand. Sci. (Geogr.) Dissertation. Irkutsk: Novosibirsk. State Pedagogical Univ., 2007. 270 p.

12. Zubenok L.I. Isparenie na kontinentakh [Evaporation on the Continents]. Leningrad: Gidrometeoizdat Publ., 1976. 295 p.

13. Kachinskii N.A. Fizika pochv [Soil Physics]. Moscow: Vysshaya Shkola Publ., 1965. 318 p.

14. Korchagin A.A., Mazirov M.A., Shushkevich N.I. Fizika pochv: laboratornyi praktikum [Soil Physics: Laboratory Workshops]. Vladimir: Vladimir. Gos. Univ., 2011. $99 \mathrm{p}$.
15. Pryakhina G.V., Zelepukina E.S., Zhuravlev S.A., Osipova T.N., Amburtceva N.I., Vinogradova T.A. The assessment of run-off from small mountain watersheds by hydrologic modelling. Vestn. Mosk. Univ., Geogr., vol. 5, 2017, no. 1, pp. 29-37. (In Russ.).

16. Rakhmanov V.V. Gidroklimaticheskaya rol' lesov [Hydroclimatic Role of Forests]. Moscow: Lesnaya Promst. Publ., 1984. 240 p.

17. Resursy poverkhnostnykh vod SSSR. Osnovnye gidrologicheskie kharakteristiki [USSR Surface Water Resources. Main Hydrological Features]. Leningrad: Gidrometeoizdat Publ., 1977, vol. 16, no. 1. 388 p.

18. Certificate of State Registration of the Computer Program No. 2018619084 "Complex Program of the Distributed Hydrological Model "Hydrograph", the Right Holder is O.M. Makarieva, Registration Date: 30.07.2018. (In Russ.).

19. Nauchno-prikladnoi spravochnik po klimatu SSSR [A Handbook to Climate of USSR], vol. 21, book 1: Krasnoyarskii krai $i$ Tuvinskaya ASSR [Krasnoyarsk Krai and Tuva Republic]. Leningrad: Gidrometeoizdat Publ. 1967. $504 \mathrm{p}$.

20. Tsymbalei Yu.M., Andreeva I.V. On accounting the landscape patterns of the catchments when assessing the water balance of water intakes (by the example of a drainage area of the Ob-Irtysh interfluve). Izv. Altaiskogo Otd. Russ. Geogr. O-va, 2015, no. 1(36), pp. 2330. (In Russ.).

21. Nash J.E., Sutcliffe J.V. River flow forecasting through conceptual models part I - A discussion of principles. J. Hydrol., 1970, vol. 10, no. 3, pp. 282-290.

22. Semenova O.M. Experience in modelling runoff formation processes at different scales using data of waterbalance stations. In Status and Perspectives of Hydrology in Small Basins (Proc. of the Workshop Held at GoslarHahnenklee, Germany, 30 March-2 April 2009). IAHS Publ., no. 336, 2010, pp. 167-172.

23. Shamseldin A.Y., O'Connor K.M. A non-linear neural network technique for updating of river flow forecasts. Hydrol. Earth Syst. Sci., 2001, vol. 5, no. 4, pp. 577-598.

24. Vinogradov Y.B., Semenova O.M., Vinogradova T.A. An approach to the scaling problem in hydrological modelling: the deterministic modelling hydrological system. Hydrol. Process., vol. 25, no. 7, pp. 1055-1073. doi 10.1002/hyp.7901

25. Zelepukina E., Pryakhina G., Shastina G., Amburtceva N., Gavrilkina S. Estimation of small mountain drainage basin runoff based on runoff formation model (West Sayan case study). In Int. Multidisciplinary Sci. Geoconf. Surveying Geology and Mining Ecology Management, SGEM. Conf. Proc. 2017, vol. 17, no. 31, pp. 245-252. doi 10.5593/sgem 2017/31 